\title{
REDUCTION OF BULLWHIP EFFECT ON COMMODITY SUPPLY CHAIN IN FRESH FRUITS AND VEGETABLES WHOLESALE LOTTEMART BOGOR
}

\author{
Bimahri Qaulan Tsaqiela*1, Yandra Arkeman ${ }^{* *}$, and Bunasor Sanim***) \\ ${ }^{*}$ Business School, Bogor Agricultural University \\ Jl. Raya Pajajaran, Bogor 16151 \\ ${ }^{* * *}$ Department of Agroindustrial Technology, Faculty of Agricultural Engineering and Technology, \\ Bogor Agricultural University \\ PO BOX 220, Campus IPB Dramaga, Bogor 16602 \\ ${ }^{* * *}$ Department of Economics, Faculty of Economics and Management, Bogor Agricultural University \\ Jl. Kamper, Wing 4 Level 5 Kampus IPB Darmaga, Bogor 16680
}

\begin{abstract}
The purpose of this study was: (1) To identify supply chain structure of fresh fruit and vegetables in LotteMart Wholesale Bogor, (2) Analyze the value of bullwhip effect in the supply chain of fresh fruit and vegetables in LotteMart Wholesale Bogor. (3) Analyze the factors that led to the bullwhip effect in the supply chain of fresh fruit and vegetables at LotteMart Wholesale Bogor, (4) Reduce the bullwhip effect in the supply chain of fresh fruit and vegetables in LotteMart Wholesale Bogor. Method that used in this research are bullwhip effect formula to analyze the value of bullwhip effect and simulation to reduce bullwhip effect with software Arena Rockwell 14.0. The results showed that fresh fruit and vegetables in LotteMart Wholesale Bogor experienced bullwhip effect and also different scenario of time between arivals distribution able to reduce bullwhip effect value in supply chain.
\end{abstract}

Keywords: supply chain, bullwhip effect, arena simulation, LotteMart

\begin{abstract}
ABSTRAK
Tujuan dari penelitian ini adalah 1) mengidentifikasi struktur rantai pasok buah dan sayuran segar di LotteMart Wholesale Bogor, 2) menganalisis nilai bullwhip effect dalam rantai pasok buah dan sayuran segar di LotteMart Wholesale Bogor, 3) menganalisis faktor-faktor yang menyebabkan efek bullwhip dalam rantai pasok buah dan sayuran segar di LotteMart Wholesale Bogor, 4) mengurangi bullwhip effect pada rantai pasok buah dan sayuran segar di LotteMart Wholesale Bogor. Metode yang digunakan dalam penelitian ini adalah rumus bullwhip effect untuk menganalisis nilai bullwhip effect dan simulasi untuk mengurangi bullwhip effect dengan Arena software Rockwell 14.0. Hasil penelitian menunjukkan bahwa buah-buahan segar dan sayuran di LotteMart Wholesale Bogor mengalami bullwhip effect dan skenario yang berbeda dari distribusi waktu antar kedatangan dapat mengurangi nilai bullwhip effect dalam rantai pasok.
\end{abstract}

Kata kunci: rantai pasok, bullwhip effect, simulasi arena, LotteMart

${ }^{1}$ Corresponding author:

Email:hellosuperbq@gmail.com

\section{INTRODUCTION}

Horticulture belongs to conmmercial commodities of high value. The sub-sector horticulture contribution to Gross Domestic Product (GDP) value from year to year tend to increase. According to the Statistic Center Bureau in 2005 the horticulture GDP increased from Rp61,79 billion to Rp89,057 billion in 2009. The increasing income per capita in Indonesia has caused a change in Indonesian people consumption pattern from the main staple to a global trend such as fresh fruits and vegetables, fish, meat, milk product, and processed foods (Chowdhury, 2004). This change of consumption pattern has given a positive impact on the development of fresh fruits and vegetables. The characteristics of fresh fruits and vegetable comodities are perishable, seasonal, and voluminous. This condition shows that fresh fruits and vegetables need supply chain from onfarm to off-farm that is well and efficiently-integrated. In the supply chain, activities begin with the provision 
of saprodi and alsintan, from the cultivation process to distribution and product marketing. Fresh fruits and vegetables are produced by farmers as the producers on farm and then distributed to modern markets. Modern markets appear to answer the people's needs because of the change in demand anf lifestyle pattern. The people's demand is more complex, since it not only emphasizes on the quality of the product, convenience, and higher value that they can get when the buy the product also become very important.

Improved income per capita also happens to Bogor City, where the increase will affect the increase of the people's purchasing power. PDRB per capita based on prices in Bogor City that was effective in 2013 was Rp19.283.951,17 or there was a positive change as much as $9,92 \%$ compared to PDRB per capita in 2012 (BPS Kota Bogor, 2014). In addition to that, Bogor City is located near the Capital City of West Java, Bandung. Its strategic location is potential to expand development, economic growth, service, national industrial center, transportation, communication and tourism (the City of Bogor). This is a driving factor for modern market growth that is rapidly developed in Bogor City.

LotteMart Wholesale Bogor is one of the modern markets in the form of wholesale that has operated for two years. This wholesaler operates with applying a buying concept that emphasizes on a low price. LotteMart Wholesale provides traders' needs (modern and traditional retailers) and end users. This is a unique concept for a modern market of wholesale-form. In general, a wholesale serves the retailers' needs. The products they buy are then resold to other consumers.

The flow of products, information, and finance happens in the supply chain of each level in LotteMart Wholesale in Bogor. The flow from the farmers to wholesalers and vice versa must be continuous. If there is a lack in the supply chain, it will become inefficient. Problem that often occurs in the supply chain that makes the supply chain performance is not efficient and optimal is distortion of information. Distortion of information happens because of the lack in coordination among the parties involved in the supply chain. Distortion of information will cause a demand pattern becomes fluctuative towards the on-farm supplier which is called a bullwhip effect. Bullwhip effect is a phenomenon in which there is an increase of fluctuation or variability of demand from the on-farm to the off-farm in one supply chain (Pujawan dan Mahendrawathi, 2010). The phenomenon is called a bullwhip effect because it is a form of demand curve for the suppliers which is like a whip that expresses fluctuation, while the demand curve for cunsumers is more flat.

LotteMart Wholesale sometimes experience problems in meeting the demand for fresh fruits and vegetables. Season and fluctuation of price are some influencing factors in fulfilling the demand. Fresh fruits and vegetables are seasnal, so that during rainy season, for example, the quantity and quality of harvest will decrease. Therefore, the quantity of supply that is delivered by wholesalers will also decrease. This will certainly affect the sale to customers. Besides, the coordination between suppliers and wholesalers is very low, so that the quantity and quality that is delivered is not suitable with the quantity and quality that has been set by the wholesalers.

Lack of supply is one of the causes of a bullwhip effect. The impact of this bullwhip effect is inefficiency in the supply chain because the doers in the supply chain have misunderstood the signal. Furthermore, another impact of a bullwhip effect is the increase of production cost, storage cost, transportation cost, delivery and acceptance cost, additional lead time, decrease of product and at last decrease in profit (Chopra dan Meindl, 2013).

For those reasons, it is important to study a Bullwhip Effect on the supply chain of fresh fruits and vegetables in modern markets. The analysis of the Bullwhip Effect in this study will use the Bullwhip Effect formula to find out the amplification of demand variabilities happening in the supply chain.

\section{METHOD}

The research was carried out in LotteMart wholesale Bogor City. This is because LotteMart wholesale serves sellers and end users. Data collection from the field were carried out in February and March 2015.

This research is a case study on the supply chain in a modern market LotteMart Wholesale Bogor on the commodities of fresh fruits and vegetables. LotteMart Wholesale Bogor was chosen because of its unique concept, namely a modern market in the form of wholesale, which has been established for 2 years, so that it is potential to experience inefficiency in the supply chain; besides, Bogor City is a supporting town for the capital city whose economic growth has developed very rapidly. 
Fresh fruits and vegetables that have been developed inlcude harumanis manggo, Red Globe USA grapes, seedless red melon, imported carrots, shallots and red chillies. The research focuses more on the information it is trying to get in order to know a problem that exists, so that appropriate information can be gained, and the number of samples taken is not an important aspect.

Data that are used in this research include primary data and secondary data. The primary data used in this research are the chain flow of fresh fruits and vegetables and a demand fulfilment system, whereas the secondary data used in this research cover data about order from wholesaler to buyers and demand from customers to wholesalers.

The research methods that are used in this research are qualitative method, quantitative method and simulation. The qualitative descriptive method is used to explain a description of fresh fruits and vegetable supply in LotteMart Wholesale Bogor and to analyze factors that cause a bullwhip effect. The major influencing factors are decentralized demand forecast updating, irregular order matching, price fluctuation, rationing and shortage gaming (Lee et al.1997; Pujawan and Mahendrawathi, 2010). Quantitavie methos are used to analyze a bullwhip effect value on the freh fruits and vegetable supply chain in LotteMart Wholesale Bogor. The formula used to calculate the bullwhip effect value is as follows:

$$
\begin{aligned}
\mathrm{BE} & =\frac{\mathrm{CV} \text { order }}{\mathrm{CV} \text { demand }} \\
\mathrm{CV} & =\frac{\mathrm{STD}}{\mathrm{AVG}} \\
\mathrm{STD} & =\frac{\sqrt{\mathrm{n} \sum \mathrm{Xi}^{2}-\left(\sum \mathrm{Xi}\right)^{2}}}{\mathrm{n}^{2}} \\
\mathrm{AVG} & =\frac{\sum_{\mathrm{n}=1}^{\mathrm{i}} \mathrm{Xi}}{\mathrm{n}}
\end{aligned}
$$

\section{Description:}

$\begin{array}{ll}\text { BE } & : \text { Bullwhip Effect } \\ \text { CV order } & : \begin{array}{l}\text { the variants' coefficient value that } \\ \text { is obtained from calculation of the } \\ \text { number of wholesaler's order }\end{array} \\ \text { CV Demand } \quad: \text { the variants' coefficient value that } \\ \\ \begin{array}{l}\text { is obtained from calculation of the } \\ \text { number of consumers' demand }\end{array} \\ \text { STD } & : \text { Standard deviation }\end{array}$

$\begin{array}{ll}\text { AVG } & : \text { Average } \\ \mathrm{Xi} & : \text { Number of raw materials order } \\ \mathrm{n} & : \text { Ordering period }\end{array}$

If the value of $\mathrm{BE}>1$, it shows that there is a demand expansion on the product. On the other hand, if $\mathrm{BE} \leq 1$, it shows that rarefaction of demand pattern shows on the related party.

Simulation is used to reduce a bullwhip effect after carrying out calculation on the bullwhip effect value and analyze the causing factors. The aim of this simulation model was to demonstrate the benefits of imrpoving the flexibility levels of of fresh fruits and vegetable supply chain, in relation to the reduction of bullwhip effect (Radulescu and Ciocardia, 2009). Liong and Loo (2009) explain that in the arena, a simulation model can be established by placing moduls simultaneously that have been set up previously, which is a process or logics.

Data within the arival time of the entities use primary data which have been processed using an input analyzer. Later on, it is used within the arrival time of the Arena simulation. After the simulation output is obtained, the results will be carried out using a bullwhip effect formula again and compared with the results of a bullwhip effect that has been previously counted. The research frame of thought is explained in Figure 1.

\section{RESULT}

\section{Structure of Supply Chain in LotteMart Wholesale Bogor}

Supply chain in LotteMart Wholesale Bogor consists of several components that are integrated. The components are suppliers, buyer, distributor, wholesaler (grocers), and customer. The headquarter of LotteMart Indonesia is called a buyer because it purchases products to suppliers, whereas LDC (Lotte Distribution Center) plays a role as a distributor.

The product to be distributed to LotteMart all over Indonesia must first be collected in LDC that is located in Pasar Rebo. After that, the products will be sent to LotteMart Wholesale as a wholesaler which will carry ot selling, namely the end-users, retailers, traders, and HOREKA (Hotel, Restaurant, Catering). 


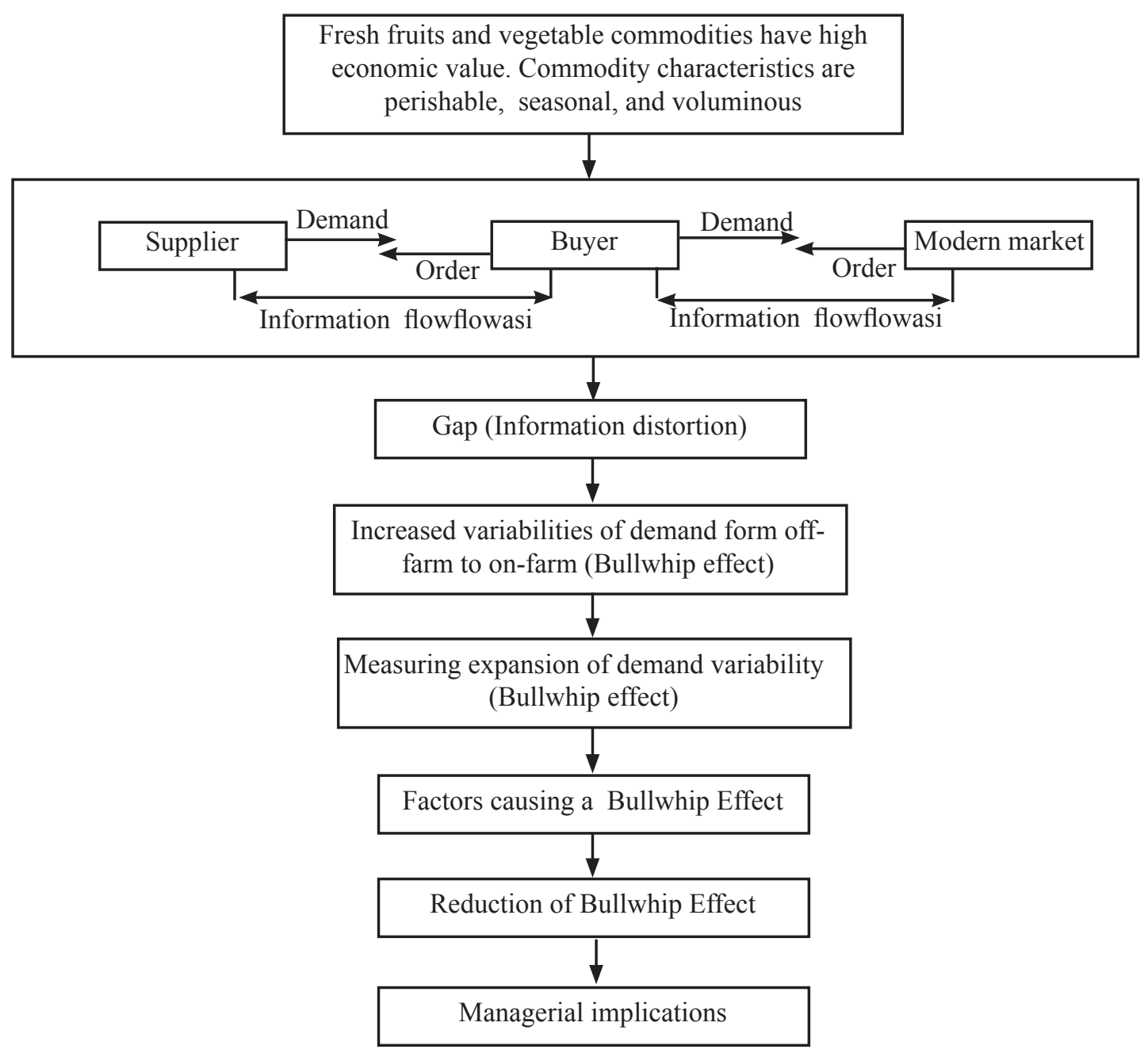

Figure 1. Frame of thought of the research

In each supply chain there is a flow of product, information and financce from the upstream to downstream of vice versa. The flow of productm informationm and finance in the LotteMart Wholesale Bogor chain started from suppliers to customers, which can be seen in Figure 2.

The structure of supply chain of LotteMart Wholesale starts from suppliers that are the suppliers of fresh products and proccessed products to LotteMart Wholesale network all over Indonesia. the suppliers are LotteMart partners that are bound with a conract. The products to be delivered must meet the standard and quality set in the contract. If the suppliers have got he informaion via email about he order from the buyers, the suppliers will soon deliver the products to the wholesaler. The wholesaler, however, has informed the order of products needed by the buyers. Fresh fruits and vegetables belong to the category fresh food so that the products must be first collected by the distributors
(LDC) before they are distributed to wholesaler. LDC only accommodate local fruits and vegetables, while imported fruits and vegetables are sent directly from the supppliers to he wholesaler.

\section{Bullwhip Effect analysis of Fresh Fruits and Vegatebles}

The analysis of bullwhip effect was carried out to find out the variability expansion of demand for fresh fruits and vegetables in LotteMart Wholesale Bogor. The analysis used data for order and demand of some freh fruits and vegetables in the last three months of the year 2014. The fresh fruits chosen are red Globe grapes from USA, harumanis manggoes, and seedless red melon. As for the fresh vegetables, those that are chosen include shallots, red chillies and imported carrots. Some fresh fruits and vegetables are chosen because they belong to the group of the highest sale level in LotteMart Wholesale. 


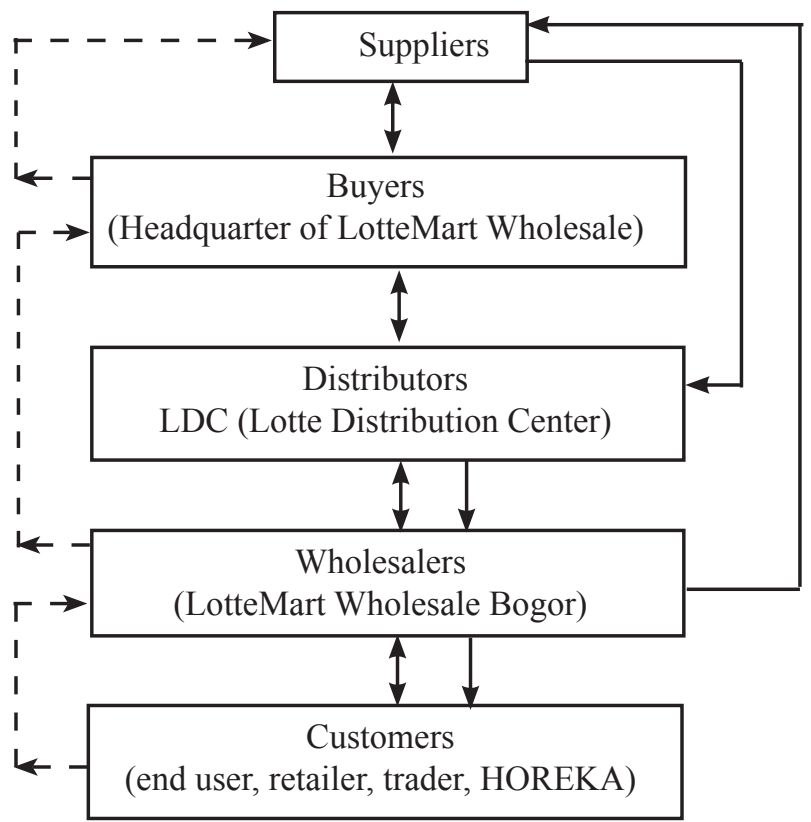

Notes:

$=$ product flow

$---\cdots--$ = financial flow

$\longrightarrow$ = information flow

Figure 2. The supply chain of LotteMart Wholesale Bogor

Calculation of order and demand data was carried out in sequence from the AVG (average) calculation until it produced BE (Bullwhip effect) using Ms. Excel. The results of the calculation that have been carried out with Ms Excel are prresented in Table 1 and Table 2.

The calculation results show the bullwhip effect value of fresh fruits for the period of October-November 2014. The BE value for the comodity of Red Globe grapes of USA was 1,31 . the value indicates that the demand variability increased or expanded 1,31 times. On the comodity of harumanis mangoes the $\mathrm{BE}$ value was 2,94 , which means that the demand variability expanded 2,94 times. On the commodity of red watermelon, the BE vale was was 2,91 , which means that the demand variability expanded 2,91 times. The calculation results indicates that the three commodities experienced the bullwhip effect.

The calculation results show the calculation of the bullwhip effect value for the period of OctoberNovember 2014, the BE value on the shallot commodity was 1,98 . the value indicates that the demand variability underwent expansion 1,98 times. The value indicated that the demand variability increased or expanded 1,98 times. As for the red chily commodity, the BE value was
0,98 , which means that in this commodity there was no demand variability expansion. On the carrot commodity the $\mathrm{BE}$ value was 1,04 which means that the demand variability increased 1,04 times. The calculation results showed that shallot and improted carrot commdities experienced the bullwhip effect, while red chilies did not experience the bullwhip effect.

The bullwhip effect value of local commodities tend to be higher than import commodities. Local commodities got basic problems in the upstream, i.e. the shortage of qualified seeds, lack of incentive the fresh fruit and vegetable farmers obtained, and incapable logistic infrastructure. Besides, the fresh fruit and vegetable farmers in Indonesia did not have a wide land, so that when the farmers would increase their production, their income would become lower because maintaining the plants would cost higher. The condition in the upstream would influence the quantity and quality of the commodities produced and the price of the commodities in the market would be high.

The gap can be seen from the flood of import commodities in Indonesian markets. This is because local comodities could not fulfill the needs from incountry, and the procedures and fiscal policy set by the government made it easy for import commodities to enter Indonesian markets. Demand for improt commodities is increasing and importers tend to be more ready to meet the customers needs than the local farmers, so that the bullwhip effect value of import comodities tend to be lower.

The expansion of demand variabilities of fresh fruits ten to be higher compared to that of fresh vegetables. This is because of the order revision caried out by LotteMart Wholesale that is conducted daily with different quantities.

The Bullwhip effect that happen to fresh fruit and vegetable commdities are influenced by various factors. The factors that influence the bullwhip effect are related to the information on order and demand. The information obtained in each level of the supply chain sometimes experience changes and tend to be decentralized so that the actual information obtained by the wholesalers could not reach the suppliers. The factors causing the bullwhip effect on the fresh fruits and vegetables in LotteMart Wholesale Bogor will be discussed later. 
Table 1. Results of the calculation of the value of fresh fruit bullwhip October-November 2014

\begin{tabular}{lrrrrrrr}
\hline \multirow{2}{*}{ Name of product } & \multicolumn{3}{c}{ Order } & \multicolumn{3}{c}{ Demand } & \multirow{2}{*}{ BE } \\
\cline { 2 - 7 } & \multicolumn{1}{c}{ AVG } & \multicolumn{1}{c}{ STD } & \multicolumn{1}{c}{ CV } & \multicolumn{1}{c}{ AVG } & \multicolumn{1}{c}{ STD } & \multicolumn{1}{c}{ CV } & \\
\hline Anggur Red Globe USA (Kg) & 979.657 & 630188,9 & 0,64 & 1.063 .349 & 523267,83 & 0,49 & 1,31 \\
Mangga Harumanis (Kg) & 5.597 .795 & 5463249,05 & 0,97 & 5.550 .433 & 1843972,96 & 0,33 & 2,94 \\
Semangka Merah Tanpa Biji (Kg) & 7.692 .649 & 1934079,5 & 0,25 & 7.616 .336 & 658309,19 & 0,09 & 2,91 \\
\hline
\end{tabular}

Table 2. Results of the calculation of the value of fresh vegetables bullwhip October-November 2014

\begin{tabular}{lrrrrrrr}
\hline \multirow{2}{*}{ Name of product } & \multicolumn{3}{c}{ Order } & \multicolumn{3}{c}{ Demand } & \multirow{2}{*}{ BE } \\
\cline { 2 - 7 } & \multicolumn{1}{c}{ AVG } & \multicolumn{1}{c}{ STD } & \multicolumn{1}{c}{ CV } & \multicolumn{1}{c}{ AVG } & \multicolumn{1}{c}{ STD } & \multicolumn{1}{c}{ CV } & \\
\hline Bawang Merah (1 Kg) & 1.242 & 113,1194 & 0,091 & 1.245 & 57,1430952 & 0,05 & 1,98 \\
Cabai Merah Tw (Kg) Kw.2 & 342.490 & 172800,1 & 0,50 & 340.214 & 174117,7 & 0,51 & 0,98 \\
Wortel Import (Kg) & 3.388 .815 & 458068,728 & 0,14 & 3.679 .302 & 476730,303 & 0,13 & 1,04 \\
\hline
\end{tabular}

\section{Factors causing the Bullwhip effect on the Fresh Fruit and Vegetables}

Based on the research conducted in LotteMart Wholesale Bogor. There are some factors that cause the wullwhip effects on the fresh fruits and vegetables, namely:

\section{Price Fluctuation}

The change in price of fruits and vegetables in traditional markets as well as modern markets happens almost every week. The price set in LotteMart Wholesale is tailored to the market price. Besides, in import fresh fruits and vegetables, the price will be subject to the price in the countries of origin so that price fluctuation often happens.

\section{Irregular order batching}

LotteMart Wholesale Bogor carried out fresh fruit and vegetable order with indefinite period of time. Delivery of fresh fruits and vegetables is in accordance with the weekly revision of order estimation that is informed by the wholesalers ever day. The products can be delivered within once in two days or even once a day, with different quantities. At the end of the week, the wholesalers will carry out an order with the quantity 1,5-2 times more than previously.

\section{Decentralized demand forecast updating}

Demand forecasting is not only conducted by wholesalers, but also by other doers in the supply chain, namely the suppliers and buyers. However, there is often a demand forecasting renewal that is caried out by wholesalers. Wholesalers contact directly their customers so that they own acual data of customers' demand that becomes a foundation for making demand forecasting. Suppliers, on the other hand, do not have the actual data, so that demand forecasting is made based on the previous order data. Change in demand forecasting happening to the supply chain of LotteMart Wholesale is not centralized so that demand variability expansion is bigger in the upstream.

\section{Reduction of the Bullwhip effect on Fresh Fruits and Vegetables Using Arena Simulation Model}

Reduction of the bullwhip effect on the fresh fruits and vegetables in this research uses the Arena Simulation software Rockwell 14.0. Previous research concerning reduction of bullwhip effect carried out by Merkuryev, Petuhova, Landeghem and Vansteenkiste (2002) used Arena Simulation software with a strategy of centralized and decentralized distributing information that is combined with 2 control policies, inventory, min-max and stock-to-demand inventory control. Simulation was carried out with four-stage supply chain, which consists of suppliers, wholesalers, distributors, and manufactures. The best result from the simulation is centralized information structural model and stock-todemand inventory control.

The research on the reduction of the bullwhip effect carried out by Radulescu and Ciocardia (2009) simulated information flow and supply chain for SME with Arena 10 software. This makes it possible for the two material and information flows to be modelled, and logical decision for planning and control. The results show that planning scenario and control are compared based on the demand pattern, product structures and processing characteristics. 
In this research the simulation was used to demonstrate the material flow with diferent time periods of arrival of the entities. The model will be run using differenttime scenarios, namely:

1. Time between arrivals of the entities is constant and time for taking distributions is triangular (TRIA($0.001,1.44 \mathrm{e}+003,2.88 \mathrm{e}+003)$ ).

2. Time between arrivals of the entities is constant and time for taking distributins is normal $(\operatorname{NORM}(1.44 \mathrm{e}+003,2.9))$.

Scenario 2 has the most number out system, namely 2.800 entities, whereas in Scenario 1, the number of entities that have been processed is 2.589 (Table 3). The entity number in shows that the number of entities belong to the system, while the entity number out shows that the number of entities that belong to the system, while the entity number out shows the number of entities that are out from the system, but are not yet processed. In both scenarios, the entity number in is 4.600 . The entity number out from the system in Scenario 1 is 3.989 entities and that in Scenario 2 is 4.200 entities.

WIP (Work in Process) shows the mumber of entities that are still in the process in the system. WIP Scenario 1 is 432,66 entities, and Scenario 2 is 292,91 entities. The utility value of workers close to zero shows that workers' productivity is better, and work division is in acordance with the capacity of each worker. The simulation results show that Scenario 2 (normal time distribution) is better than Scenario 1 (triangular time distribution).
The number of entities from each simulation scenario is used to calculate the BE value in order to compare the $\mathrm{BE}$ values before and after the simulation. The results of the calculation and the comparison of BE values will be described in Table 4 and Table 5.

Scenario 1 and Scenario 2 produce the $\mathrm{BE}$ values les than 1 , namely 0,14 and 0,23 , which indicates that there is no demand variability expansion. When the initial $\mathrm{BE}$ value is more than 1 , it indicates that there is a demand variability expansion. This shows that time distribution among arrivals can reduce the $\mathrm{BE}$ value. The results of the simulation and calculation of $\mathrm{BE}$ after simualtion shows that Scenario 2 with time between arrivals is normal.

\section{Managerial Implications}

A good supply chain planning is one of the ways to reduce the bullwhip effect. The supply chain planning for easily-damaged products is focused more on colaboration between suppliers and buyers, such as a contract between a supermarket and farmers based on the multi-eselon supply theory and some sopporting materials for food industrial practices of vegetables, to improve collaborations between various stakeholders (Lee, 2011; Rabade, 2006; Hingley, 2005). LotteMart Wholesale Bogor, in this case, is a wholesaler that has a colaboration with suppliers so that the imformation flow from LotteMart should be in two-ways. Suppliers must get an access to actual data of sales thorugh the internet that is connected to the inforation center of LotteMart.

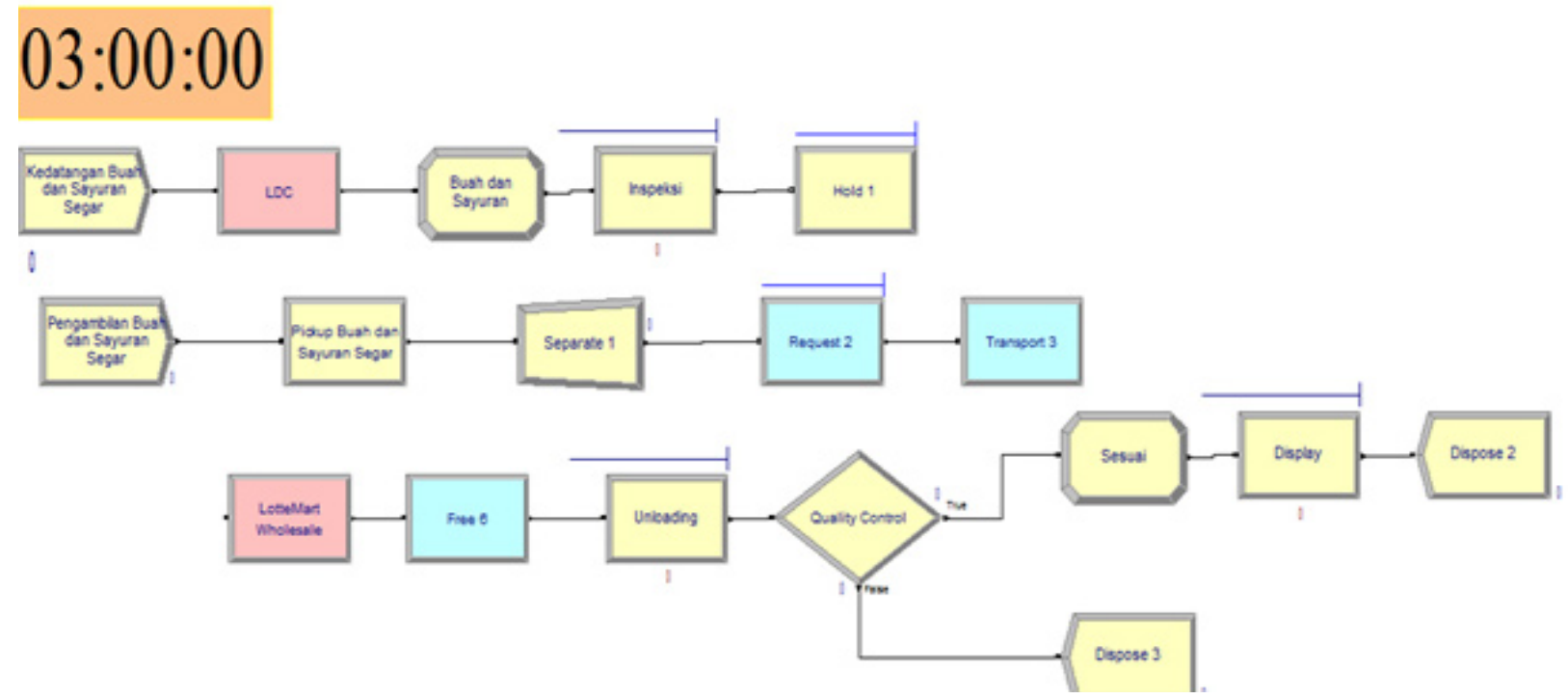

Figure 3. Model entities stream LotteMart Wholesale Bogor on arena 
Table 3. Output SIMAN simulation Arena

\begin{tabular}{lcc}
\hline \multirow{2}{*}{ Variable } & \multicolumn{2}{c}{ Scenarios } \\
\cline { 2 - 3 } & 1 & 2 \\
\hline System Number Out (Kg) & 2.589 & 2.800 \\
Entity Number In (Kg) & 4.600 & 4.600 \\
Entity Number Out (Kg) & 3.989 & 4.200 \\
WIP & 432,66 & 292,91 \\
Utilities: & & \\
Inspector 1 & 0,23 & 0,23 \\
Inspector 2 & 0,23 & 0,23 \\
Inspector 3 & 0,23 & 0,23 \\
Unloading Officer 1 & 0,41 & 0,44 \\
Unloading Officer 2 & 0,41 & 0,46 \\
Unloading Officer 3 & 0,41 & 0,42 \\
\hline
\end{tabular}

Table 4. The calculation of the value of BEA onion scenarios 1 and 2

\begin{tabular}{|c|c|c|c|c|c|c|c|}
\hline \multirow[t]{2}{*}{ scenario } & \multicolumn{3}{|c|}{ Order } & \multicolumn{3}{|c|}{ Demand } & \multirow[t]{2}{*}{$\mathrm{BE}$} \\
\hline & AVG & STD & $\mathrm{CV}$ & AVG & STD & $\mathrm{CV}$ & \\
\hline scenario 1 & 1533,33 & 33,50 & 0,02 & 863 & 137 & 0,16 & 0,14 \\
\hline scenario 2 & 1533,33 & 33,50 & 0,02 & 933,33 & 86,50 & 0,09 & 0,23 \\
\hline
\end{tabular}

Table 5. Comparison of BE values of Shallots before and after the simulation

\begin{tabular}{ccc}
\hline Initial BE & BE Scenario 1 & BE Scenario 2 \\
\hline 1,98 & 0,14 & 0,23 \\
\hline
\end{tabular}

Time distribution between the entity arrivals (fresh fruits and vegetables) can reduce the expansion of demand variabilities or the bullwhip effect in the supply chain of LotteMart Wholesale. Estimation of order should be set every Tuesday and Friday, or its frequency every week so that the order period is regular. The supply chain manager should conduct a planning of order periods of fresh fruits and vegetables that is based on product charecteristics and that is in accordance with the needs. Etilen rate, climaterics, non-claimaterics, are some characteristics that must get attention. When the fresh vegatbles have been received by Quality Control (QC), the QC should carry out storing and display according to the characteristics of the product, for example vegetable A can be stored in the chiller, while vegetable B cannot.

\section{CONCLUSIONS AND RECOMMENDATIONS}

\section{Conclusions}

Based on the analysis results and discussion of the research, it can be concluded as follows: 1) Fresh fruit and vegetable commodities that undergo the bullwhip effect or expansion of demand variabilities are US
Red Globe grapes, Harumanis manggoes, seedless watermelon, shallots, and imported carrots. Chillies, on the other hand, do not undergo the bullwhip effect. 2) Factors causing the bullwhip effect in the supply chain of LotteMart Wholesale are price fluctuation, irregular order batching, decentralized demand forecast updating. 3) The best scenario is Scenario 2 whose time distribution between arrival is constant, and time between taking is normal distribution. The bullwhip effect value is reduced after Arena simulation is conducted with 2 scenarios of normal time distribution and triangular time distribution. The first $\mathrm{BE}$ value 1,98 changes to become 0,14 and 0,23 . This shows that there is no demand variability expansion on the products. 4) The bulwhip effect values of fresh fruit and vegetable commodities are lower than the local fresh fruit and vegatable commodities, because during that time demand for imported commodities is increasing, and the importers tend to be more ready to meet the customers' demand than the local farmers.

\section{Recommendations}

The recommendations that can be given to companies and to improve further research on the same subject are as follows: 1) LotteMart Wholesale is expected to be 
able to determine regular order periods and centralize information on actual demand data. 2) Further research is expected to be able to compare the results between decentralized information and centralized information on the supply chain to reduce the bullwhip effect. 3) Further research is also expected to be able to analyze the bulwhip effect values in all elements of the supply chain from the upstream to downstream.

\section{REFERENCES}

[BPS Kota Bogor] Badan Pusat Statistik Kota Bogor. 2014. http://www.bogorkota.bps.go.id/. [Juni 2015].

[BPS] Badan Pusat Statistik. 2014. Statistik Indonesia. http://www.bps.go.id. [September 2014].

[Pemkot Bogor] Pemerintah Kota Bogor. 2011. Penyelenggaraan Pemerintahan Daerah. http:// www.kotabogor.go.id. [Juni 2015].

Chopra S, Meindl P. 2013. Supply Chain Management: Strategy, Planning \& Operations, 5th Edition. Pearson Prentice Hall.

Chowdurry SK, Gulati A, Sa'id EG. 2004. The Rise of Supermarkets and Vertical Relationships in the Indonesian Food Value Chain: Causes and Consequences. Asian Journal of Agriculture and Development $2(1,2)$.

Hingley M. 2005. Relationship Development in the UK Fresh Produce Supply Chain. Journal of Marketing Channels 12(1): 27-50. http://dx.doi. org/10.1300/J049v12n01_03

Lee HL, Padmanabhan V, Whang S. 1997. Information distortion in a supply chain: The bullwhip effect. Management Science 43(4) : 546-558.http:// dx.doi.org/10.1287/mnsc.43.4.546
Lee J, Palekar US, Qualls W. 2011. Supply Chain Efficiency and Security: Coordination for Collaborative Investment in Technology. European Journal of Operational Research 210: 568-578. http://dx.doi.org/10.1016/j. ejor.2010.10.015

Liong CY, Loo CSE. 2009. A Simulation Study of Warehouse Loading and Unloading Systems Using Arena. Journal of Quality Measurement and Analysis 5(2): 45-56.

Merkuryev YA, Petuhova JJ, Landeghem RV, Vansteenkiste S. 2002. Simulation-Based Analysis of The Bullwhip Effect Under Different Information Sharing Strategies. Proceedings 14th European Simulation Symposium.

Merkuryev YA, Petuhova JJ, Landeghem RV, Vansteenkiste S. 2002. Simulation-Based Analysis of The Bullwhip Effect Under Different Information Sharing Strategies. Proceedings 14th European Simulation Symposium.

Pujawan I, Mahendrawathi. 2010. Supply Chain Management: edisi kedua. $\quad \mathrm{P}$ e $\mathrm{n}$ e $\mathrm{r}$ b i t Guna Widya. Surabaya.

Rabade LA, Alfaro JA. 2006. Buyer-Supplier Relationship's Influence on Traceability ImplementationinTheVegetableIndustry. Journal of Purchasing \& Supply Management 12:39-50. http://dx.doi.org/10.1016/j.pursup.2006.02.003

Radulescu AV, Ciocardia RM. 2009. Simulation of The Information Flow and Supply Chain Using Arena Modelling Software. Annals of DAAAM for 2009 \& Proceedings of the 20th International DAAAM Symposium 20(1).

Reddy GP, Murthy MRK, Meena PC. 2010. Value Chains and Retailing of Fresh Vegetables and Fruits, Andhra Pradesh. Agricultural Economics Research Review 23 : 455-460. 